\title{
Oil Soluble Corrosion Inhibitor on Microbiologically Influenced Corrosion in Diesel Transporting Pipeline
}

\author{
N. Muthukumar, S. Maruthamuthu, S. Mohanan, N. Palaniswamy* \\ Corrosion Protection Division, Central Electrochemical Research Institute, \\ Karaikudi - 630 006, India
}

Received 3 August 2006; accepted 8 November 2006

\begin{abstract}
The effect of oil soluble commercial corrosion inhibitors (OSCI) on the growth of bacteria and its corrosion inhibition efficiency were investigated. Corrosion inhibition efficiency was studied by rotating cage test and the nature of biodegradation of corrosion inhibitor was also analyzed by using FTIR, NMR and GC-MS. This isolate has the capacity to degrade the aromatic and aliphatic hydrocarbon present in the corrosion inhibitors. The degraded products of corrosion inhibitors and bacterial activity determine the electrochemical behaviour of API 5LX steel. The influence of bacterial activity on degradation of corrosion inhibitor and its influence on corrosion of API 5LX have been evaluated by employing weight loss techniques and electrochemical studies. The present study also emphasizes the importance of evaluation of oil soluble corrosion inhibitor in stagnant model (flow loop test) and discusses the demerits of the oil soluble corrosion inhibitors in petroleum product pipeline.
\end{abstract}

Keywords: diesel pipeline, corrosion inhibitors, rotating cage method, flow loop method, biodegradation, microbiologically influenced corrosion.

\section{Introduction}

The possible effects of corrosion inhibitor on bacteria are of considerable interest to people involved in oil and gas production and transmission pipelines. It is possible that corrosion inhibitors will have biocidal effects on bacteria [1]. Organic film-forming inhibitors used in the oil and gas industry are generally of the cationic/anionic type and include imidazolines, primary amines, diamines, amino-amines, oxyalkylated amines, fatty acids, dimer-trimer acids, naphthaneic acid, phosphate esters and dodecyl benzene sulphonic acids. Their mechanism of action is to form a persistent monolayer film adsorbed at the metal/solution interface. It is well known that bacteria can oxidize a wide variety of chemicals and use them as nutrient source and enhance the proliferation of bacteria [2-4]. However aerobic bacteria and fungi participate in the corrosion process [5-7].

\footnotetext{
* Corresponding author. E-mail address: swamy23@rediffmail.com
} 
The microorganisms influence the corrosion by altering the chemistry at the interface between the metal and the bulk fluid [8-9]. Thus, the alteration of the molecule of the inhibitor caused by microbial degradation during its use, which can affect their specific performance on corrosion inhibition [10]. Microbial degradation of simple heterocyclic inhibitor of the type morpholine $\left(\mathrm{C}_{4} \mathrm{H}_{9} \mathrm{NO}\right)$ has been recently reported by Poupin et al. [11]. Bento et al. [12] and Muthukumar et al. [13] have reported the understanding of the microbial species involved in microbial corrosion and their interactions with metal surfaces. The degradation involved an enzymatic attack at the $\mathrm{C}-\mathrm{N}$ position, followed by ring cleavage to produce glycolic acid [11]. Dominguez et al. [14] reported the loss in efficiency of organic corrosion inhibitors in the presence of Pseudomonas fluorescence isolated from injection water system used in off-sore oil production. Recently Maruthamuthu et al. [15] and Rajasekar et al. [4] have noticed the degradation of corrosion inhibitors and their effect on the corrosion process in a petroleum product transporting pipeline at Northwest, India. In petroleum product pipelines, it would be better to know if the oil soluble corrosion inhibitor (OSCI) is acting as a nutrient source or as biocide or indeed whether what its effect at all. In the present study, a laboratory experiment was designed to evaluate the degradation of corrosion inhibitor by employing dominating individual species (Serratia marceneus ACE2, Bacillus cereus ACE4) and their role on corrosion process in petroleum products.

\section{Experimental}

\section{Background information of the study}

A cross-country pipeline in India, transports petroleum products such as kerosene, petrol and diesel. This pipeline has intermittent petroleum product delivery at different locations. Severe corrosion and microfouling problems have been faced in the pipeline eventhough corrosion inhibitor was added. About 200 to $400 \mathrm{~kg}$ of muck (corrosion product) were received from a $200 \mathrm{~km}$ stretch of the pipeline within 30 days [15]. The corrosion product was pushed out of the pipeline by pigs (cylindrical device that moves with the flow of oil and cleans the pipeline interior) while cleaning the pipeline. The corrosion product samples were collected in sterile containers for microbial enumeration and identification. In the present study, commercially available oil soluble corrosion inhibitor used in petroleum transporting pipeline was evaluated to find out the nature of degradation, which was used in petroleum pipeline. The oil soluble commercial corrosion inhibitor contains amine based mono-carboxylic acid compounds.

\section{Microorganism}

The strains Serratia marcescens ACE2 and Bacillus cereus ACE 4 [4] used in this study were isolated from oil transporting pipeline of oil refineries in North west India (the nucleotide sequences data has been deposited in GenBank under the sequence numbers DQ092416 and AY912105). 


\section{Composition of growth medium}

The medium used for detecting the corrosion inhibitor degrading process by ACE4 was Bushnell-Hass broth (magnesium sulphate- $0.20 \mathrm{gm} / \mathrm{L}$; calcium chloride-0.02 gm/L; monopotassium phosphate-1 gm/L; di-potassium phosphate$1 \mathrm{gm} / \mathrm{L}$; ammonium nitrate-1 $\mathrm{gm} / \mathrm{L}$; ferric chloride-0.05 gm/L, Hi-Media, Mumbai) and Bushnell-Hass agar. Three sets of Erlenmeyer flasks were used for the inhibitor degradation studies using the selected bacterial strains.

\section{Biodegradation of corrosion inhibitor and their characterization}

Two sets of Erlenmeyer flasks containing $100 \mathrm{~mL}$ of the BH broth, $400 \mathrm{ppm}$ of water soluble corrosion inhibitor with ACE2 and ACE4 were inoculated. An uninoculated control flask was incubated parallelly to monitor abiotic losses of the corrosion inhibitor substrate. The flasks were incubated at $30{ }^{\circ} \mathrm{C}$ for 30 days in an orbital shaker $(150 \mathrm{rpm})$. At the end of the 30 days of incubation period, the residual corrosion inhibitor for each system of the entire flask was extracted with an equal volume of dichloromethane. Evaporation of solvent was carried out in a hot water bath at $40{ }^{\circ} \mathrm{C}$. The $1 \mu \mathrm{L}$ of the resultant solution was analyzed by Fourier transform infrared spectroscopy (FTIR) and $\mathrm{H}^{1}$ Nuclear magnetic resonance spectroscopy (NMR). FTIR spectrum, (Nicolet Nexus 470) was taken in the mid IR region of $400-4000 \mathrm{~cm}^{-1}$ with 16 -scan speed. The samples were mixed with spectroscopically pure $\mathrm{KBr}$ in the ratio of 1:100 and the pellets were fixed in the sample holder, and the analysis was carried out. Infrared peaks localized at 2960 and $2925 \mathrm{~cm}^{-1}$ were used to calculate the $\mathrm{CH}_{2} / \mathrm{CH}_{3}$ ratio (absorbance) and functional group of both aliphatic and aromatic components present in water soluble corrosion inhibitor. $\mathrm{H}^{1} \mathrm{NMR}$ (Bruker, $300 \mathrm{~m} \mathrm{~Hz}$ ) analysis was used to detect the protons of the nuclei in the diesel compound. The sample of diesel was dissolved using deutrated chloroform solvent. Tetra methyl silane (TMS) was used as a reference standard. The $1 \mu \mathrm{L}$ of the resultant corrosion inhibitor solution was analyzed by thermo finnigan gas chromatography / mass spectrometry (trace MS equipped with a RTX-5 capillary column (30 m long $\times$ $0.25 \mathrm{~mm}$ internal diameter) and high purity nitrogen as carrier gas. The oven was programmed between 80 and $250{ }^{\circ} \mathrm{C}$ at a heating temperature of $10{ }^{\circ} \mathrm{C} / \mathrm{min}$. The $\mathrm{GC}$ retention data of the inhibitor correspond to structural assignations done after NIST library search with a database and by mass spectra interpretation.

\section{Inhibitor efficiency test}

Rotating cage test

Corrosion inhibition efficiency was studied by rotating cage test [16, ASTM G170]. API 5LX grade steel (C-0.29 max, S-0.05 max, P-0.04 max, Mn-1.25 max.) coupons of size $2.5 \times 2.5 \mathrm{~cm}$ were mechanically polished to mirror finish and then degreased using trichloro ethylene. Four coupons supported by polytetro fluro ethylene (PTFE) disks were mounted at $55 \mathrm{~mm}$ apart on the rotatory rod. Holes were drilled in the top and bottom PTFE plates of the cage in order to increase the turbulence on the inside surface of the coupon. The rotatory rod runs at $200 \mathrm{rpm}$, which corresponds to a linear velocity of $0.53 \mathrm{~m} / \mathrm{s}$. In the present study, $500 \mathrm{~mL}$ of diesel with $2 \%$ water containing $120 \mathrm{ppm}$ chloride as a 
system-I (control); $500 \mathrm{~mL}$ of diesel with $2 \%$ water containing $120 \mathrm{ppm}$ chloride and $2 \mathrm{~mL}$ of mixed cultures of ACE2 and ACE4 control system-II; $500 \mathrm{~mL}$ of diesel with $2 \%$ water containing $120 \mathrm{ppm}$ chloride and $100 \mathrm{ppm}$ of oil soluble inhibitor (OSCI) is marked as system-III; while $500 \mathrm{~mL}$ diesel with $2 \%$ of water containing $120 \mathrm{ppm}$ chloride, $100 \mathrm{ppm}$ of oil soluble inhibitor(OSCI) inoculated with $2 \mathrm{~mL}$ of mixed cultures of ACE2 and ACE4 were used as the experimental systems IV.

Flow loop test-for simulating the stratification of water in pipe flow

In order to simulate this sort up condition, a flow loop setup was fabricated [16, ASTM G170]. The flow loop system consists of a reservoir that maintains the solution under test, a pump with piping and control system that allows the solution to flow. Flow loop model has been made in laboratory with creating stagnant water in the pipeline for simulating the field conditions. The low velocity region is maintained in the cylindrical PVC pipe having a length of 20 $\mathrm{cm}$ and diameter of $12 \mathrm{~cm}$. The suction line precedes the cylindrical device and the out let from the device is connected to the reservoir. The experimental setup was washed by water thoroughly and dried well. The polished metal coupons were suspended in the setup in the hook provided. In the present study, the following systems were made. $8000 \mathrm{~mL}$ diesel $+2 \%$ water (120 ppm chloride) as a system-V (control); $8000 \mathrm{~mL}$ of diesel with $2 \%$ water containing $120 \mathrm{ppm}$ chloride and $2 \mathrm{~mL}$ of mixed cultures of ACE2 and ACE4 system-VI; $8000 \mathrm{~mL}$ of diesel with $2 \%$ water containing $120 \mathrm{ppm}$ chloride and $100 \mathrm{ppm}$ of oil soluble inhibitor(OSCI) is marked as experimental system-VII; while $8000 \mathrm{~mL}$ diesel with $2 \%$ of water containing $120 \mathrm{ppm}$ chloride, $100 \mathrm{ppm}$ of oil soluble inhibitor(OSCI) inoculated with $2 \mathrm{~mL}$ of mixed cultures of ACE2 and ACE4 were used as the experimental system VIII.

After 7 days, the coupons were removed and washed in Clark's solution for 1 min to remove the corrosion products and rinsed with sterile distilled water, dried. Final weights of the six coupons in each system were taken and the average corrosion rates were also calculated and standard deviations are also presented. The inhibition efficiency (IE) was calculated as follows:

$$
\text { Inhibition efficiency }(\mathrm{IE} \%)=\frac{W-W_{i n h}}{W} \times 100
$$

where $\mathrm{W}_{\text {inh }}$ and $\mathrm{W}$ are the values of the weight-loss of steel after immersion in solutions with and without inhibitor, respectively.

\section{Electrochemical methods for the evaluation of inhibitor}

After the weight loss experiments (rotating test), electrochemical tests were carried out in a special cell containing aqueous medium collected from the rotating cage $[17,4]$. API 5LX steel coupon of size $1 \mathrm{~cm}^{2}$ as working electrode, a standard calomel electrode (SCE) and platinum wire as counter electrode were employed for impedance and polarization studies. An EG \& G electrochemical impedance analyzer (Model M6310 with software M398) was used for AC impedance measurements. After attainment of a steady state potential an AC signal of $10 \mathrm{mV}$ amplitude was applied and impedance values were measured for 
frequencies ranging from $0.01 \mathrm{~Hz}$ to $100 \mathrm{~Hz}$. The values of $R_{t}$ were obtained from the Bode plots. After finishing the impedance study, the same coupons were used for polarization for avoiding the film disturbance in the oxide film in presence of bacteria. The Tafel polarization curves were obtained by scanning the potential from the open circuit potential towards $200 \mathrm{mV}$ anodically and cathodically. The scan rate was $120 \mathrm{mV} / \mathrm{min}$. Polarization measurements were carried out potentiodynamically using model PGP201, employing potentiostat with volta master-1-software.

\section{Surface analysis study}

To verify the adsorption of inhibitor on the metal surface in rotating cage test after 7 days, the film formed on the metal surface was carefully removed and dried, mixed thoroughly with potassium bromide $(\mathrm{KBr})$ and made as pellets. These pellets are subjected to FTIR spectra (Perkin-Elmer, Nicolet Nexus -470) to find out the protective film formed on the surface of the metal coupons. The surface morphological characteristics of the control and experimental carbon steel were observed under scanning electron microscope (SEM) Hitachi model S$3000 \mathrm{H}$ at magnification ranging from $50 \mathrm{X}$ to $200 \mathrm{X}$ operated at accelerating voltage of $25 \mathrm{kV}$.

\section{Results and discussion}

In oil pipelines, water can also stratify at the bottom of line if the velocity is less than that required to entrain water and sweep it through the pipeline system. Liquids (hydrocarbon) stratify along the bottom of the pipe, with water forming a separate layer beneath the liquids where hydrocarbon degradation occurs at the interface easily by microbes. Hence, the role of bacteria on degradation and corrosion is an important area in petroleum product pipelines. The involvement of bacterial species on corrosion inhibitor degradation and corrosion has been studied by various investigators $[18-20,15]$ and is available on the involvement of bacterial species on corrosion inhibitor degradation and corrosion. It is the first study that enlightens the role of individual species of Bacillus cereus ACE4 on biodegradation of corrosion inhibitor in petroleum products and its influence on corrosion process in tropical countries.

\section{Biodegradation analysis}

Oil soluble inhibitor

FT-IR spectrum of oil soluble inhibitor (OSCI) shows (Fig. 1a) the presence of the methyl $\left(\mathrm{CH}_{3}\right)$ and methylene $\left(\mathrm{CH}_{2}\right)$ aliphatic saturated $\mathrm{C}-\mathrm{H}$ stretching band which are observed at $2922 \mathrm{~cm}^{-1}$ and $2853 \mathrm{~cm}^{-1}$, respectively. The $\mathrm{C}=\mathrm{O}$ stretching band is observed at $1707 \mathrm{~cm}^{-1}$; it is due to the presence of carboxylic acid group. The peaks at 1459 and $1413 \mathrm{~cm}^{-1}$ is due to aromatic C-C stretching band. The C$\mathrm{N}$ asymmetric stretching is observed at $1374 \mathrm{~cm}^{-1}$. The peak at $1283 \mathrm{~cm}^{-1}$ is due to aromatic C-O-C delocalization band. The peak at $934 \mathrm{~cm}^{-1}$ is due to the substituted benzene ring. The aromatic bending band occurs at the range of 813$723 \mathrm{~cm}^{-1}$. 


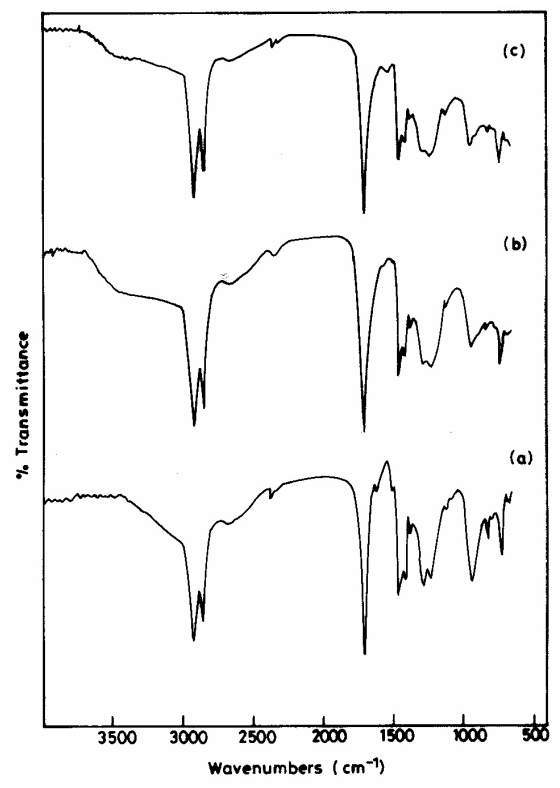

Figure 1. Fourier transform infrared spectrum. a) Oil soluble corrosion inhibitor (uninoculated system-control); b) inoculated with Serratia marcenus ACE 2; and c) inoculated with Bacillus cereus ACE 4.

In the FT-IR spectrum of oil soluble inhibitor (OSCI) in Serratia marceneus ACE 2 bacterial inoculated system, (Fig. 1b) shows the aliphatic methyl $\left(\mathrm{CH}_{3}\right)$, methylene $\left(\mathrm{CH}_{2}\right), \mathrm{C}-\mathrm{H}$ stretching bands which are observed at 2922 and $2853 \mathrm{~cm}^{-}$ ${ }^{1}$, respectively. The $\mathrm{C}=\mathrm{O}$ stretching band is observed at $1708 \mathrm{~cm}^{-1}$. The $\mathrm{C}-\mathrm{C}$ stretching band at $1459 \mathrm{~cm}^{-1}$. The peak at $1237 \mathrm{~cm}^{-1}$ is due to aromatic $\mathrm{C}-\mathrm{O}-\mathrm{C}$ delocalization band. The olefinic $(=\mathrm{C}-\mathrm{H})$ out of plane bending band is observed at $723 \mathrm{~cm}^{-1}$. The less intensity of peak at $813 \mathrm{~cm}^{-1}$, (benzene ring out of plane bending band) is due to the consumption of aromatic compound by the bacterial activity.

In the FT-IR spectrum of oil soluble corrosion inhibitor (OSCI) in Bacillus cereus ACE 4 bacterial inoculated system, (Fig. 1c) shows the aliphatic methyl $\left(\mathrm{CH}_{3}\right)$, methylene $\left(\mathrm{CH}_{2}\right), \mathrm{C}-\mathrm{H}$ stretching bands being observed at 2921 and 2852 $\mathrm{cm}^{-1}$, respectively. The $\mathrm{C}=\mathrm{O}$ stretching band is observed at $1707 \mathrm{~cm}^{-1}$. The $\mathrm{C}-\mathrm{C}$ stretching band at 1459 and $1411 \mathrm{~cm}^{-1}$ is observed. The peak at $1233 \mathrm{~cm}^{-1}$ is due to aromatic $\mathrm{C}-\mathrm{O}-\mathrm{C}$ delocalization band. The olefinic $(=\mathrm{C}-\mathrm{H})$ out of plane bending band is observed at $723 \mathrm{~cm}^{-1}$. The disappearance of peak at $813 \mathrm{~cm}^{-1}$, (benzene ring out of plane bending band) is due to the consumption of aromatic compound by the bacterial activity.

The NMR spectrum of oil soluble inhibitor (OSCI) is presented in the Fig. 2a.

The aromatic proton peak is observed at $7 \mathrm{ppm}$ as a singlet peak. The olefinic $(\mathrm{C}-\mathrm{H})$ proton peak occurs at $5.32 \mathrm{ppm}$. The amine protons are observed at 3 $2.79 \mathrm{ppm}$ and 2.29-1.9 and the aliphatic methylene $\left(\mathrm{CH}_{2}\right)$ protons peak is observed at 1.59 and $1.29 \mathrm{ppm}$. A methyl proton $\left(\mathrm{CH}_{3}\right)$ peak can be noticed at $0.87 \mathrm{ppm}$. In the NMR spectrum of oil soluble inhibitor in bacteria ACE 4 inoculated system (Fig 2b), two types of olefinic protons are observed. The singlet peak at $6.1 \mathrm{ppm}$ is for olefinic protons; formed from the decomposition of aromatic ring and the olefinic proton peaks can be observed as single peak at 
$5.33 \mathrm{ppm}$. The amine proton peaks are observed at $2.82 \mathrm{ppm}$ and in the range between 2.02 and 2.19. The aliphatic methylene proton peaks are observed at 1.5 and 1.28 and the methyl proton peak is observed at $0.91 \mathrm{ppm}$.

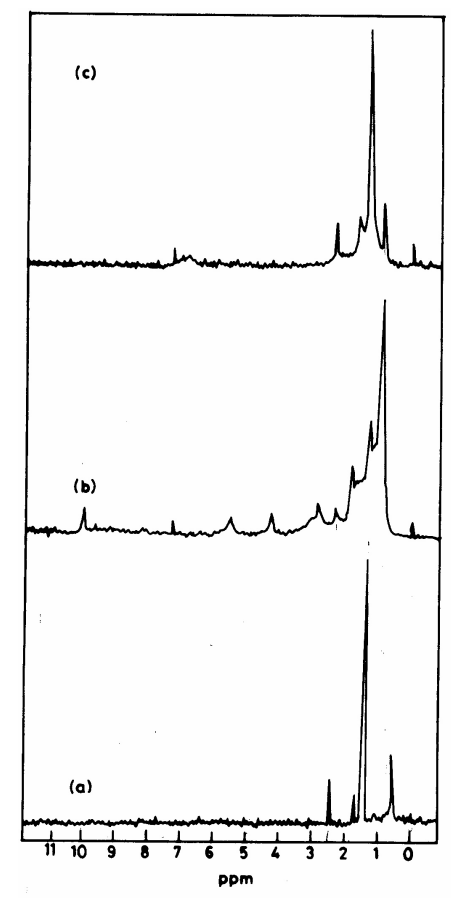

Figure 2. $\mathrm{H}^{1}$ NMR spectrum. a) Oil soluble corrosion inhibitor (uninoculated systemcontrol); b) inoculated with Serratia marcenus ACE 2; and c) inoculated with Bacillus cereus ACE 4.

The GC retention data of the oil soluble inhibitor (OSCI) corresponding to structural assignations done after library search with a database and by mass spectra interpretation are presented in Table 1. From the GC-MS analysis (Fig 3), it was observed that the corrosion inhibitor (uninoculated system) consists of aliphatic hydrocarbons including 2-docene-1-yl(-) succinic anhydride, bis (2ethylhexyl) phthalate. These compounds were major components present in the oil soluble corrosion inhibitor and their molecular weight is about 266 and 520, respectively.

Table 1. GC-MS data of oil soluble corrosion inhibitor (OSCI).

\begin{tabular}{llcc}
\hline $\begin{array}{c}\text { Retention time } \\
\text { (min) }\end{array}$ & Compound & $\begin{array}{c}\text { Molecular } \\
\text { formula }\end{array}$ & $\begin{array}{c}\text { Molecular } \\
\text { weight }\end{array}$ \\
\hline 9.05 & 2-docene-1-yl(-) succinic anhydride & $\mathrm{C}_{16} \mathrm{H}_{26} \mathrm{O}_{3}$ & 266 \\
9.56 & 2-docene-1-yl(-) succinic anhydride & $\mathrm{C}_{16} \mathrm{H}_{26} \mathrm{O}_{3}$ & 266 \\
9.86 & 2-docene-1-yl(-) succinic anhydride & $\mathrm{C}_{16} \mathrm{H}_{26} \mathrm{O}_{3}$ & 266 \\
10.15 & 2-docene-1-yl(-) succinic anhydride & $\mathrm{C}_{16} \mathrm{H}_{26} \mathrm{O}_{3}$ & 266 \\
10.32 & 2-docene-1-yl(-) succinic anhydride & $\mathrm{C}_{16} \mathrm{H}_{26} \mathrm{O}_{3}$ & 266 \\
10.82 & 2-docene-1-yl(-) succinic anhydride & $\mathrm{C}_{16} \mathrm{H}_{26} \mathrm{O}_{3}$ & 266 \\
11.14 & 2-docene-1-yl(-) succinic anhydride & $\mathrm{C}_{16} \mathrm{H}_{26} \mathrm{O}_{3}$ & 266 \\
12.94 & 2-docene-1-yl(-) succinic anhydride & $\mathrm{C}_{16} \mathrm{H}_{26} \mathrm{O}_{3}$ & 266 \\
16.22 & bis (2-ethylhexyl) phthalate & $\mathrm{C}_{27} \mathrm{H}_{36} \mathrm{O}_{10}$ & 520 \\
& [1,2-benzene dicarboxylic acid bis & & \\
& (2-ethylhexyl) ester] & & \\
\hline
\end{tabular}




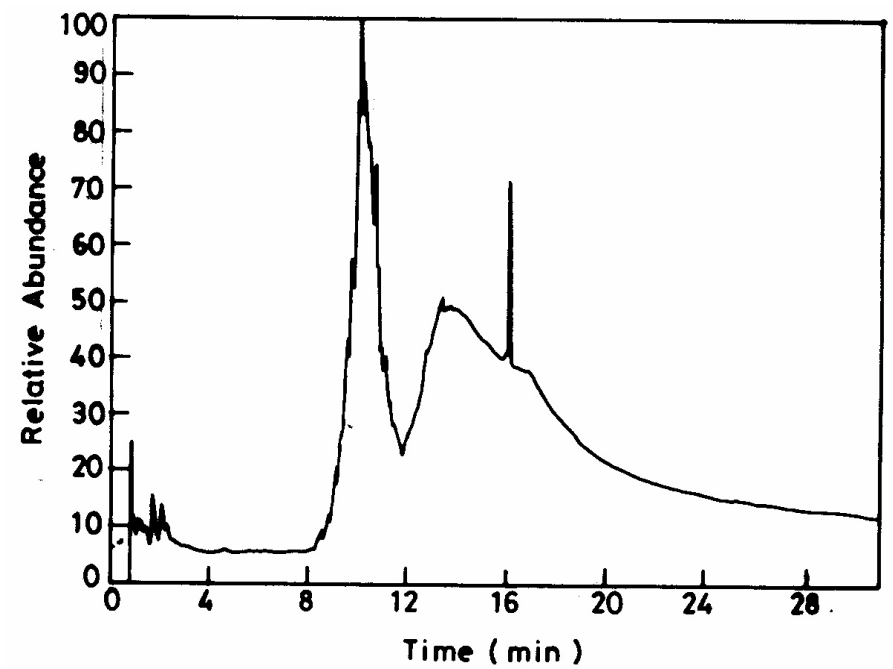

Figure 3. GC-MS spectrum of pure oil soluble inhibitor.

In the presence of OSCI with ACE2 (Fig 4), it utilizes the aliphatic and aromatic components and the new peaks at 1.70, 3.79, 6.54, 7.42, 7.59, 8.38, 9.19, 9.94 retention time, which indicates that the new compounds are benzene,1-methyl-2(1-methylethyl), naphthalene,2-methyl, benzene,1,1'-ethylidenebis, benzene,1,1'methylenebis[4-methyl, benzene, 1,1'-methylenebis[4-methyl, 3,5,3',5'tetramethyl biphenyl, 1,5,6,7-tetrame-thyl-3-phenylbicyclo[3,2,0]hepta-2,6diene, respectively. It is due to the decomposition or degradation of aromatic compounds (Table 4). The finding suggests that the strain ACE2 has the high preference to degrade both aliphatic and aromatic components and the molecular weight is reduced in the range between 142 to 224 .

In presence of OSCI with ACE4 (Fig 5), shows new peaks at 1.69, 3.77, 5.39, $6.31,6.54,7.42,7.58,8.37,9.18,9.94,10.29,11.10$ retention time which indicates that the new compounds are benzene,1,1'-methylenebis[4-methyl, naphthalene,2-methyl, 1,1'-biphenyl,2-methyl, benzene,1,1',1', 1','[1.6-hexadiylidene]-tetrakis, benzene 1,5,6,7-tetramethyl-3-phenylbicyclo[3,2,0]hepta-2,6diene, benzene, 1,1'-methylenebis[4-methyl, benzene, 1,1'-methylenebis[4-methyl 3,5,3',5'-tetramethyl biphenyl, 1,5,6,7-tetramethyl-3-phenylbicyclo[3,2,0]hepta2,6-diene, 1,5,6,7-tetramethyl-3-phenylbicyclo[3,2,0]hepta-2,6-diene,1,5,6,7tetramethyl-3-phenylbicyclo[3,2,0]hepta-2,6-diene, dibutylthalate, respectively. It is due to the decomposition or degradation of aromatic compounds (Table 4). The finding suggests that the strain ACE4 has the high preference to degrade both aliphatic and aromatic components.

The present study reveals that the isolator has the capacity to degrade both the aromatic and aliphatic hydrocarbon in the oil soluble corrosion inhibitor(OSCI) in petroleum product pipeline. Videla et al. (2000) also noticed microbial degradation of film forming inhibitor and observed that Pseudomonas sp. isolated from injection water degraded several aromatic compounds and generated energy for its metabolic activity. They also suggested that dimethylamine, imidazoline, morpholine, cyclo hexylamine and quaternary ammonium compounds are biodegradable. 


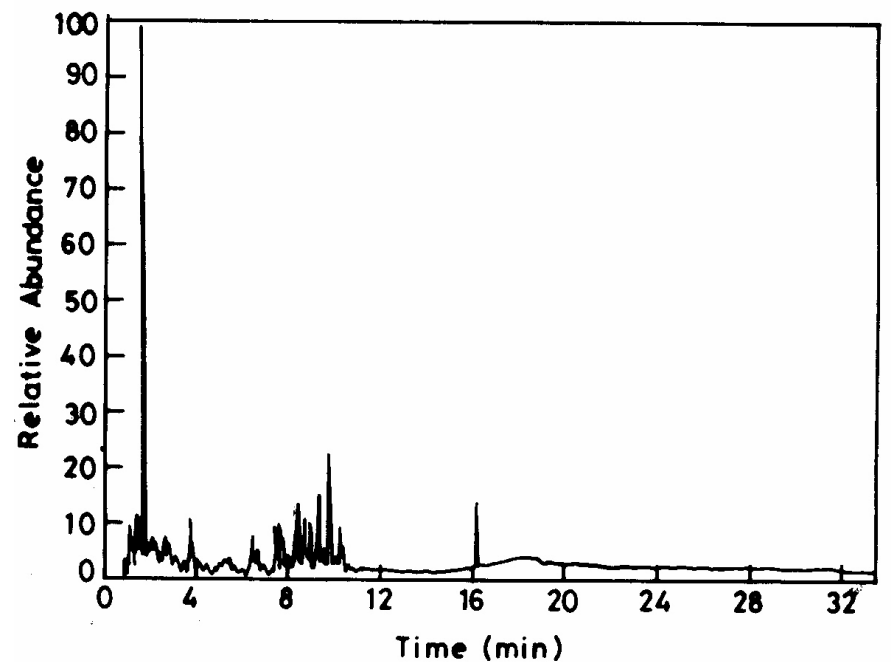

Figure 4. GC-MS spectrum of oil soluble inhibitor inoculated with ACE2.

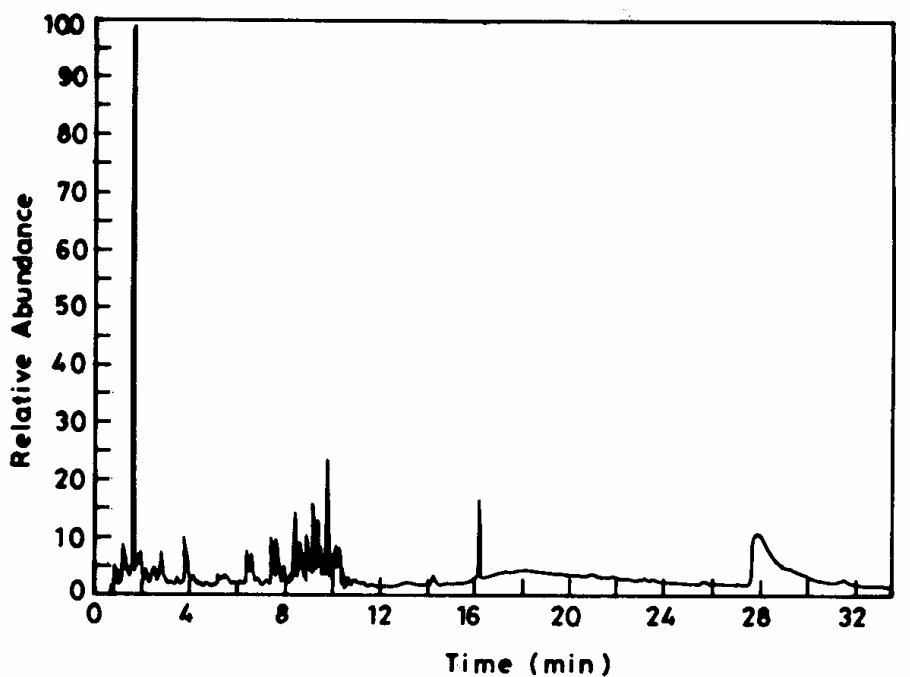

Figure 5. GC-MS spectrum of oil soluble inhibitor inoculated with ACE4.

Table 2. GC-MS data of OSCI after 30 days of inoculation with strain Serratia marceneus ACE 2.

\begin{tabular}{lccc}
\hline $\begin{array}{l}\text { Retention } \\
\text { time (min) }\end{array}$ & Compound & $\begin{array}{c}\text { Molecular } \\
\text { formula }\end{array}$ & $\begin{array}{c}\text { Molecular } \\
\text { weight }\end{array}$ \\
\hline 1.70 & benzene,1-methyl-2-(1-methylethyl) & $\mathrm{C}_{10} \mathrm{H}_{14}$ & 224 \\
3.79 & naphthalene,2-methyl- & $\mathrm{C}_{11} \mathrm{H}_{10}$ & 142 \\
6.54 & $\begin{array}{c}\text { benzene,1,1'-ethylidenebis- } \\
\text { \{ethane 1,1- diphenyl\} }\end{array}$ & $\mathrm{C}_{14} \mathrm{H}_{14}$ & 182 \\
& & & \\
7.42 & benzene,1,1'-methylenebis[4-methyl- & $\mathrm{C}_{15} \mathrm{H}_{16}$ & 196 \\
7.59 & benzene,1,1'-methylenebis[4-methyl- & $\mathrm{C}_{15} \mathrm{H}_{16}$ & 196 \\
8.38 & $3,5,3$ ',5'-tetramethyl biphenyl & $\mathrm{C}_{16} \mathrm{H}_{18}$ & 210 \\
9.19 & $1,5,6,7-$ tetramethyl-3- & $\mathrm{C}_{17} \mathrm{H}_{20}$ & 224 \\
9.94 & phenylbicyclo[3,2,0]hepta-2,6-diene & & \\
& $1,5,6,7-$ tetramethyl-3- & $\mathrm{C}_{17} \mathrm{H}_{20}$ & 224 \\
& phenylbicyclo[3,2,0]hepta-2,6-diene & & \\
\hline
\end{tabular}




\section{Inhibitor efficiency}

Rotating cage test

The inhibition efficiency (IE) of oil soluble corrosion inhibitor is presented in Table 3.

Table 3. Corrosion rates of API 5LX with OSCI in rotating system.

\begin{tabular}{|c|c|c|c|c|}
\hline $\begin{array}{l}\text { Sl. } \\
\text { No }\end{array}$ & System & $\begin{array}{l}\text { Weight } \\
\text { loss (mg) }\end{array}$ & $\begin{array}{c}\text { Corrosion } \\
\text { Rate } \\
\text { (mmpy) }\end{array}$ & $\begin{array}{c}\text { Inhibition } \\
\text { efficiency } \\
(\%)\end{array}$ \\
\hline 1. & $\begin{array}{l}\text { System I: } 500 \mathrm{~mL} \text { of diesel }+5 \% \text { water } \\
\text { (containing } 120 \mathrm{ppm} \text { chloride) }\end{array}$ & 26.5 & 0.3262 & --- \\
\hline 2. & $\begin{array}{l}\text { System II: } 500 \mathrm{~mL} \text { of diesel }+5 \% \text { water } \\
\text { (containing } 120 \text { ppm chloride) }+ \\
\text { bacterial culture }\end{array}$ & 41.7 & 0.5133 & --- \\
\hline 3. & $\begin{array}{l}\text { System III: } 500 \mathrm{~mL} \text { of diesel }+2 \% \\
\text { water (containing } 120 \mathrm{ppm} \text { chloride })+ \\
\text { OSCI ( } 250 \mathrm{ppm})\end{array}$ & 10 & 0.1230 & 62 \\
\hline 4. & $\begin{array}{l}\text { System IV: } 500 \mathrm{~mL} \text { of diesel }+5 \% \\
\text { water (containing } 120 \mathrm{ppm} \text { chloride })+ \\
\text { bacterial culture }+ \text { OSCI }(250 \mathrm{ppm})\end{array}$ & 30 & 0.3690 & 29 \\
\hline
\end{tabular}

The corrosion rate of API 5 LX in control system (without inoculum) is in the range between $0.3262 \mathrm{~mm} /$ year up to $168 \mathrm{hrs}$. In the presence of microbes and absence of corrosion inhibitor (system-II), the corrosion rate is higher in the range between $0.5133 \mathrm{~mm} /$ year when compared to the absence of microbes. Oil soluble corrosion inhibitor(OSCI) gives inhibition efficiency in the range between $62 \%$, while in presence of oil soluble corrosion along with bacteria, the inhibition efficiency is in the range between $29 \%$. The present observation reveals that bacteria reduces the efficiency of oil soluble corrosion inhibitor.

Flow loop method

The inhibition efficiency (IE) of oil soluble corrosion inhibitor is presented in Table 4. The corrosion rate of API 5 LX in control system (system V, without inoculum) is in the range between $0.0440 \mathrm{~mm} /$ year up to $168 \mathrm{hrs}$. In presence of microbes and absence of corrosion inhibitor (system-VI), the corrosion rate is higher in the range between $0.0890 \mathrm{~mm} /$ year when compared to the absence of microbes. Oil soluble corrosion inhibitor gives inhibition efficiency in the range between $31 \%$ (system VII) while in the presence of oil soluble corrosion along with bacteria, the inhibition efficiency is in the range between $-27 \%$ (system VIII). The present observation reveals that bacteria reduces the efficiency of oil soluble corrosion inhibitor (OSCI). 
Table 4. Corrosion rates of API 5LX with OSCI in flow loop system.

\begin{tabular}{|c|c|c|c|c|}
\hline Sl.No & System & $\begin{array}{l}\text { Weight } \\
\text { loss (g) }\end{array}$ & $\begin{array}{l}\text { Corrosion } \\
\text { rate }\end{array}$ & $\begin{array}{l}\text { Inhibition } \\
\text { efficiency } \\
(\%)\end{array}$ \\
\hline 1. & $\begin{array}{l}\text { System V: } 8000 \mathrm{~mL} \text { of diesel }+2 \% \text { water } \\
\text { (containing } 120 \mathrm{ppm} \text { chloride) }\end{array}$ & 7.56 & 0.0440 & --- \\
\hline 2. & $\begin{array}{l}\text { System V1: } 8000 \mathrm{~mL} \text { of diesel }+2 \% \text { water } \\
\text { (containing } 120 \mathrm{ppm} \text { chloride) }+ \text { bacterial } \\
\text { culture }\end{array}$ & 15.3 & 0.0891 & --- \\
\hline 3 & $\begin{array}{l}\text { System VII: } 8000 \mathrm{~mL} \text { of Diesel }+2 \% \\
\text { water (containing } 120 \mathrm{ppm} \text { chloride) }+ \\
\text { OSCI (100 ppm) }\end{array}$ & 5.2 & 0.0303 & 31 \\
\hline 4 & $\begin{array}{l}\text { System VIII: } 8000 \mathrm{~mL} \text { of diesel }+2 \% \\
\text { water (containing } 120 \mathrm{ppm} \text { chloride })+ \\
\text { Bacterial culture }+ \text { OSCI }(100 \mathrm{ppm})\end{array}$ & 9.6 & 0.0558 & -27 \\
\hline
\end{tabular}

\section{Surface analysis}

SEM picture of the metal surface was recorded before and after treatment with inhibitor (Fig. 6a-6d).

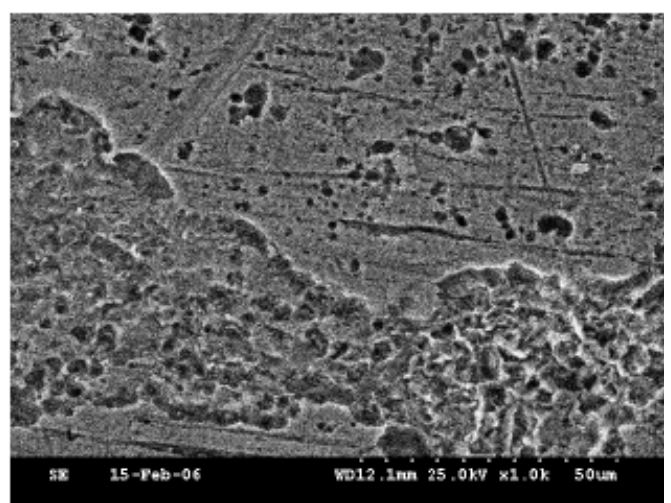

a)

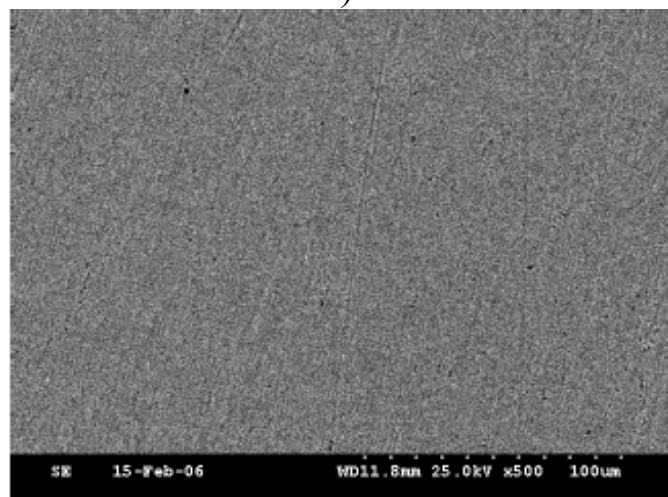

c)

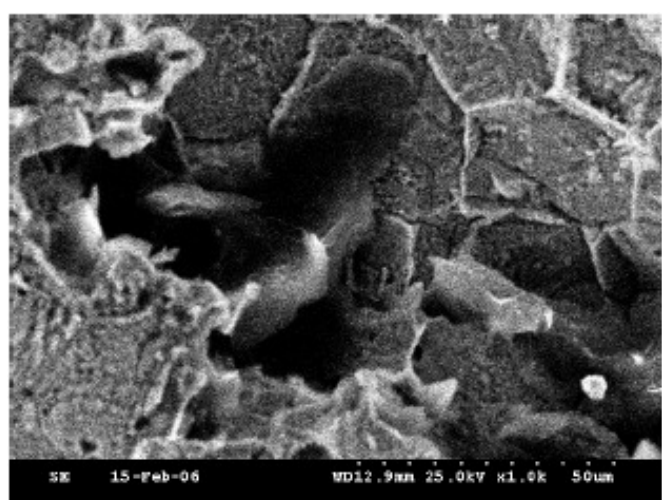

b)

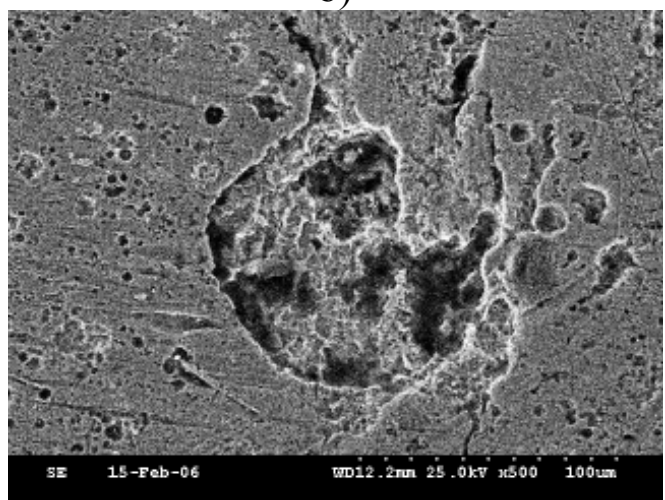

d)

Figure 6. Scanning electron micrograph of API 5LX in the absence and presence of inhibitor. a. system I, b. system II, c. system III, d. system VI

As seen from the picture in absence of inhibitor (Fig. 6a) pitting type of corrosion was observed whereas in presence of inhibitor (OSCI) there was only very mild 
and uniform corrosion (Fig. 6c). The pitting type corrosion was taken place in the presence of bacterial culture alone and along with inhibitor system (Fig. 6b- 6d).

\section{Electrochemical study}

Fig. 7. shows the polarization curve for API 5LX in diesel-water systems in the presence and in the absence of mixed culture (ACE 2 and ACE4) and oil soluble corrosion inhibitor. The data collected from polarization are presented in Table 5.

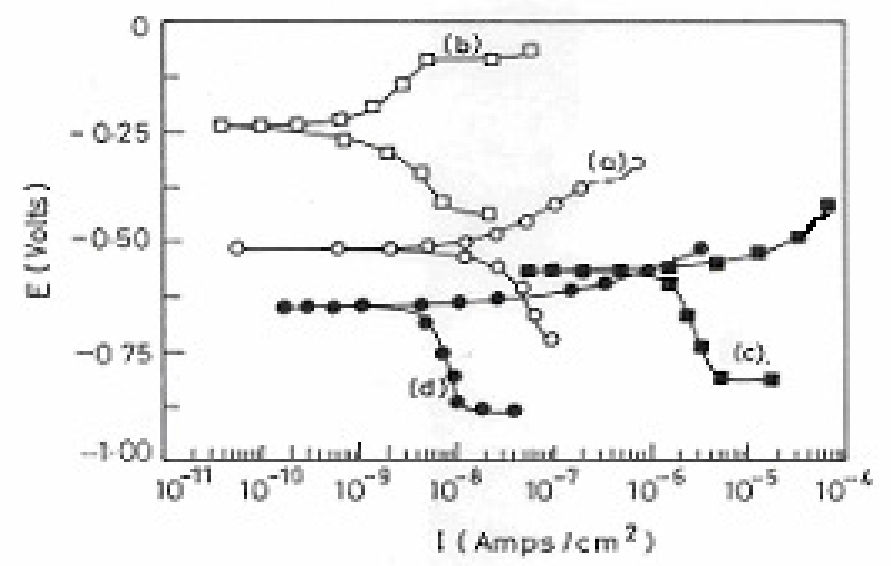

Figure 7. Polarization curve for API 5LX in diesel water system, in presence and absence of oil soluble corrosion inhibitor in rotating cage system: (a) $500 \mathrm{~mL}$ diesel + $2 \%$ water; (b) $500 \mathrm{~mL}$ diesel $+2 \%$ water $+2 \mathrm{~mL}$ mixed cultures (ACE 2 And ACE 4); (c) $500 \mathrm{~mL}$ diesel $+2 \%$ water + OSCI $(100 \mathrm{ppm})$; (d) $500 \mathrm{~mL}$ diesel $+2 \%$ water + OSCI (100 ppm) $+2 \mathrm{~mL}$ mixed cultures (ACE 2 And ACE 4).

Table 5. Polarization and impedance of data for the oil soluble corrosion inhibitor in rotating cage system.

\begin{tabular}{|l|l|c|c|c|c|c|c|}
\hline $\begin{array}{c}\text { Sl. } \\
\text { no }\end{array}$ & \multicolumn{1}{|c|}{ System } & $\begin{array}{c}\mathbf{E}_{\text {corr }} \\
\text { Volts })\end{array}$ & $\begin{array}{c}\mathbf{B}_{\mathbf{a}}(\mathrm{mV} / \\
\text { decade })\end{array}$ & $\begin{array}{c}\mathbf{B}_{\mathbf{c}}(\mathrm{mV} / \\
\text { decade })\end{array}$ & $\begin{array}{c}\mathbf{I}_{\text {corr }} \\
\left(\mathrm{A} / \mathrm{cm}^{2}\right)\end{array}$ & $\begin{array}{c}\mathbf{R}_{\mathbf{t}}(\mathrm{ohm} . \\
\left.\mathrm{cm}^{2}\right)\end{array}$ & $\begin{array}{c}\mathbf{C}_{\mathbf{d l}} \\
(\mathbf{F})\end{array}$ \\
\hline 1. & $\begin{array}{l}\text { System I (control): diesel+2\% } \\
\text { water }\end{array}$ & -0.515 & 137 & 314 & $2.63 \times 10^{-8}$ & $1.79 \times 10^{6}$ & $6.64 \times 10^{-10}$ \\
\hline 2. & $\begin{array}{l}\text { System II: diesel+2 \% water } \\
+2 \text { mL mixed cultures (ACE } \\
\text { 2 and ACE 4) }\end{array}$ & -0.580 & 142 & 645 & $4.75 \times 10^{-6}$ & $8.77 \times 10^{3}$ & $4.72 \times 10^{-7}$ \\
\hline 3. & $\begin{array}{l}\text { System III: diesel+2\% water } \\
+ \text { OSCI (100 ppm) }\end{array}$ & -0.240 & 192 & 191 & $1.80 \times 10^{-9}$ & $4.83 \times 10^{7}$ & $1.75 \times 10^{-8}$ \\
\hline 4. & $\begin{array}{l}\text { System IV: diesel+2\% water } \\
+2 \text { mL mixed cultures (ACE } \\
2 \text { and ACE 4) + OSCI (100 } \\
\text { ppm) }\end{array}$ & -0.658 & 030 & 434 & $4.34 \times 10^{-9}$ & $4.54 \times 10^{6}$ & $6.75 \times 10^{-9}$ \\
\hline
\end{tabular}

In the presence of diesel system the corrosion current was $2.63 \times 10^{-8} \mathrm{~A} / \mathrm{cm}^{2}$. While adding inhibitor the corrosion current decreased to $1.80 \times 10^{-9}$. In the presence of diesel with bacteria the corrosion current increased $\left(4.7 \times 10^{-6}\right)$, while adding inhibitor in presence of bacteria the current was $4.3 \times 10^{-9}$. It indicates that inhibitor reduces the current significantly without bacteria. But in the presence of bacteria inhibitor does not give significant reduction in corrosion current. It 
reveals that bacteria accelerate corrosion and it interferes the inhibitive action of corrosion inhibitor. The corrosion potential $\left(\mathrm{E}_{\text {corr }}\right)$ indicates the shifts the OCP from $-515 \mathrm{mV} /$ decade vs. SCE to $-240 \mathrm{mV} /$ decade in presence of inhibitor and while in presence of bacteria shifts the potential to negative side. It also reveals that the bacterial contamination interferes with the inhibitive action.

The total resistance $\left(\mathrm{R}_{\mathrm{t}}\right)$ and double layer capacitance $\left(\mathrm{C}_{\mathrm{dl}}\right)$ values were derived from the impedance measurements and presented in the Table 6 and Fig 9; the resistance $\left(R_{t}\right)$ values for control system and bacterial system are in the range between $1.79 \times 10^{6} \mathrm{ohm} \mathrm{cm}^{2}$ and $8.77 \times 10^{3} \mathrm{ohms}^{2}$. In the presence of oil soluble corrosion inhibitor and inhibitor with mixed cultures (ACE2 and ACE4), the $R_{t}$ value is $4.83 \times 10^{7}$ ohm.cm ${ }^{2}$ and $4.54 \times 10^{6}$ ohm.cm ${ }^{2}$, respectively. The $R_{t}$ value of oil soluble corrosion inhibitor is higher when compared to inhibitor with bacterial cultures. It can be explained that due to the degradation of inhibitor the efficiency decreased. It may be due to the bacteria degraded the oil soluble corrosion inhibitor in diesel/water system. It supports the polarization and weight loss results.

Fig. 8 shows the polarization curve for API 5LX in diesel-water systems in the presence and in the absence of mixed culture (ACE 2 and ACE4) and oil soluble corrosion inhibitor (OSCI). The data collected from polarization are presented in Table 6.

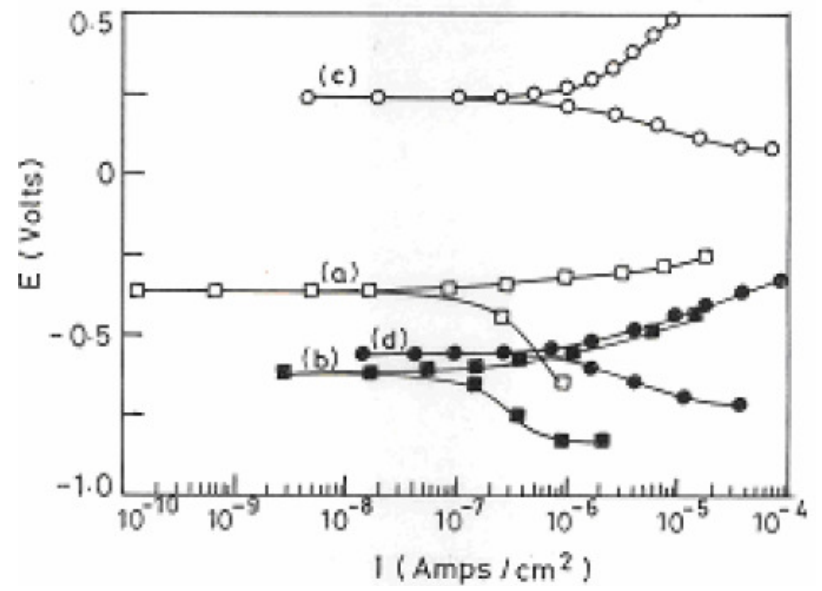

Figure 8. Polarization curve for API 5LX in diesel water system, in the presence and absence of oil soluble corrosion inhibitor in flow loop system: (a) $500 \mathrm{~mL}$ diesel $+2 \%$ water; (b) $500 \mathrm{~mL}$ diesel $+2 \%$ water $+2 \mathrm{~mL}$ mixed cultures (ACE 2 And ACE 4); (c) $500 \mathrm{~mL}$ diesel $+2 \%$ water + OSCI (100 ppm); (d) $500 \mathrm{~mL}$ diesel $+2 \%$ water + OSCI $(100 \mathrm{ppm})+2 \mathrm{~mL}$ mixed cultures (ACE 2 And ACE 4).

In the presence of diesel system the corrosion current was $1.58 \times 10^{-7} \mathrm{~A} / \mathrm{cm}^{2}$. While adding inhibitor the corrosion current decreased to $1.04 \times 10^{-6}$. In presence of diesel with bacteria the corrosion current increased to $1.05 \times 10^{-5}$, while adding inhibitor in presence of bacteria the current was $9.56 \times 10^{-7}$. It indicates that the inhibitor reduces the current significantly without bacteria. But in the presence of bacteria the inhibitor does not give significant reduction in corrosion current. It reveals that bacteria accelerate corrosion and it interferes with the inhibitive action of corrosion inhibitor. The corrosion potential $\left(\mathrm{E}_{\mathrm{corr}}\right)$ indicates 
the shifts the OCP from $-350 \mathrm{mV} /$ decade vs. SCE to $232 \mathrm{mV} /$ decade in the presence of the inhibitor and while in presence of bacteria shifts the potential to negative side. It also reveals that the bacterial contamination interferes the inhibitive action.

The total resistance $\left(\mathrm{R}_{\mathrm{t}}\right)$ and double layer capacitance $\left(\mathrm{C}_{\mathrm{dl}}\right)$ values were derived from the impedance measurements and presented in the Table 6 and Fig 8; the resistance $\left(R_{t}\right)$ values for control system and bacterial system are in the range between $2.46 \times 10^{3} \mathrm{ohm} \mathrm{cm}$ and $2.73 \times 10^{3} \mathrm{ohms} \mathrm{cm}^{2}$. In the presence of oil soluble corrosion inhibitor and inhibitor with mixed cultures (ACE2 and ACE4), the $R_{t}$ value is $4.52 \times 10^{3}$ ohm. $\mathrm{cm}^{2}$ and $4.00 \times 10^{3}$ ohm.cm ${ }^{2}$, respectively.

Table 6. Polarization and impedance of data for the oil soluble corrosion inhibitor in flow loop system.

\begin{tabular}{|l|l|c|c|c|c|c|c|}
\hline $\begin{array}{l}\text { Sl. } \\
\text { no }\end{array}$ & System & $\begin{array}{c}\mathbf{E}_{\text {corr }} \\
(\mathrm{mV})\end{array}$ & $\begin{array}{c}\mathbf{B}_{\mathrm{a}}(\mathrm{mV} / \\
\mathrm{decade})\end{array}$ & $\begin{array}{c}\mathbf{B}_{\mathbf{c}}(\mathrm{mV} / \\
\mathrm{decade})\end{array}$ & $\begin{array}{c}\mathbf{I}_{\text {corr }}(\mathrm{A} / \\
\left.\mathrm{cm}^{2}\right)\end{array}$ & $\begin{array}{c}\text { Rt }(\mathrm{ohm} . \\
\left.\mathrm{cm}^{2}\right)\end{array}$ & $\begin{array}{c}\mathbf{C}_{\mathrm{dl}} \\
(\mathrm{F})\end{array}$ \\
\hline 1. & System V: diesel+5\% water & -350 & 0.036 & 0.377 & $1.58 \times 10^{-7}$ & $2.46 \times 10^{3}$ & $7.42 \times 10^{-9}$ \\
\hline 2. & $\begin{array}{l}\text { System VI: diesel+5\%water } \\
\text { bacterial culture }\end{array}$ & -605 & 0.102 & 0.350 & $1.05 \times 10^{-5}$ & $2.73 \times 10^{3}$ & $8.85 \times 10^{-6}$ \\
\hline 3 & $\begin{array}{l}\text { System VII: diesel+5\% } \\
\text { water + OSCI (100 ppm) }\end{array}$ & 232 & 0.239 & 0.100 & $1.04 \times 10^{-6}$ & $4.52 \times 10^{3}$ & $1.75 \times 10^{-5}$ \\
\hline 4 & $\begin{array}{l}\text { System VIII: diesel +5\% } \\
\text { water + culture + OSCI (100 } \\
\text { ppm) }\end{array}$ & -558 & 0.129 & 0.109 & $9.56 \times 10^{-7}$ & $4.00 \times 10^{3}$ & $3.04 \times 10^{-5}$ \\
\hline
\end{tabular}

The $\mathrm{R}_{\mathrm{t}}$ value of oil soluble corrosion inhibitor is higher when compared to inhibitor with bacterial cultures. It can be explained that due to the degradation of inhibitor the efficiency decreased. It may be due to the bacteria to degrade the oil soluble corrosion inhibitor in diesel/water system.

Hence, the selection of good non-biodegradable inhibitor or good biocide is very important for petroleum product pipelines.

\section{Conclusions}

1. Microbial activity can result in inhibitor degradation, which would lead to unacceptable level of turbidity, corrosion of pipeline and souring of stored products. Hence, the quality of degradation characteristics should be checked by microbes collected at the pipeline.

2. FTIR, NMR and GCMS results reveal that Serratia marcescens ACE 2 is major aliphatic and aromatic hydrocarbon degrader, when compared to Bacillus cereus ACE 4.

3. The weight loss data and electrochemical studies reveal that bacterial culture reduces the efficiency of the inhibitor. It is due to the degradation of the inhibitor in the system. The reduction in the efficiency of the inhibitor is higher in flow loop method when compared to rotating cage method. It 
indicates that the water stagnant point in the flow system may enhance the inhibitor degradation, which may affect the inhibition efficiency.

4. The present study reveals that non-degradable corrosion inhibitor is needed for petroleum product pipeline to avoid the microbial degradation of corrosion inhibitors.

\section{References}

1. D.H. Pope et al., Mitigation strategies for microbiologically influenced corrosion in gas industry facilities, CORROSION/89, paper no.192 (Houston, TX: NACE,1989).

2. L.H. Lin et.al., Org. Geochem. 4,5 (1989) 511-523.

3. H. Kobayashi, B.E. Rittman, Environmen. Sci. Technol. 16, 3 (1982) 170183.

4. A. Rajasekar, S. Maruthamuthu, N. Palaniswamy, A. Rajendran, Biodegradation of corrosion inhibitors and their influence on petroleum product pipeline, Microbiological Research (2006) (in press).

5. F.M. Bento and C.C. Gaylarde, Biodeterioration of stored diesel oil: studies in Brazil, Int. Biodeterior. Biodeg. 47 (2001) 107-112.

6. J. L. Shennan, (1988) Control of microbial contamination of fuels in storage. 248-254. In D.R. Houghton, R.N. Smith, and H.O.W. Eggins (ed.), Biodeterioration, Elsevier, Barking.

7. H.A. Videla and W.G. Characklis, Biofouling and microbially influenced corrosion, Int. Biodeterior. Biodeg. 29 (1992) 195-212.

8. D.A. Jones and P.S. Amy, A thermodynamic interpretation of microbiologically influenced corrosion, Corrosion. 58 (2002) 638-645.

9. B. Little and R. Ray, A perspective on corrosion inhibition by biofilms, Corrosion. 58 (2002) 424-428.

10. H.A. Videla, S.G.G. Saraiva, P.S. Guiamet, Microbial degradation of filmforming inhibitors and its possible effects on corrosion inhibition performance, corrosion/2000, paper no.00386 (Houston, TX, NACE International, 2000).

11. P. Poupin, N. Truffaut, B. Combourieu, B. Besse, P. Sancelme, M.H. Veschambre, A.M. Delort, Applied and Environmental Microbiology 64, 1 (1998) 159.

12. F. Bento, I.B. Beech, C.C. Gaylarde, G.E. Englert and I.L. Muller, Degradation and corrosive activities of fungi in a diesel-mild steel-aqueous system, World Journal of Microbiology Biotechnology 21 (2005) 135142.

13. N. Muthukumar, S. Mohanan, S. Maruthamuthu, P. Subramanian, N. Palaniswamy, M. Raghavan, Role of Brucella sp. and Gallionella sp. in oil degradation and corrosion, Electrochem. Comm. 5 (2003) 421-427.

14. R. Dominguez, J.R.G.G. Caloca, J.M. Flores, E.M.I. Nunez, "Study on the Presence of Pseudomonas fluorescens on the Efficacy of Three Corrosion Inhibitors," (in Spanish), 3rd NACE Latin American Region Corrosion Congress, Cancun, Q.Roo, Mexico, Book of abstracts, 51-52, 1998. 
15. S. Maruthamuthu, S. Mohanan, A. Rajasekar, N. Muthukumar, P. Ponmarippan, P. Subramanian, N. Palaniswamy, Role of corrosion inhibitor on bacterial corrosion in petroleum product pipelines, Ind. J. Chem. Tech (In press).

16. S. Papavinasam, R.W. Review, M. Attard, A. Demoz, H. Sun, J.C. Donini, K.H. Michaelian, Laboratory methodologies for corrosion inhibitor selection, Material Performance 39 (8) (2000) 58.

17. E.R. Schiapparelli, B.R. Meybaum, Microbial contamination and corrosion of aircraft integral fuel storage tanks - Evaluation and risk control, Material Performance 19 (10) (1980) 47.

18. E.R. Freiter, Effect of a corrosion inhibitor on bacteria and microbiologically influenced corrosion, Corrosion 48, 4 (1992) 266-276.

19. R. Prasad, Selection of Corrosion Inhibitors to Control Microbiologically Influenced Corrosion, CORROSION/98, paper no. 276, (Houston, TX: NACE International, 1998).

20. H.A. Videla, S.G.G. Saravia, P.S. Guiamet, Microbial degradation of filmforming inhibitors and its possible effects on Corrosion inhibition performance, corrosion/2000, paper no.00386 (Houston, TX, NACE International, 2000). 